\title{
Democracy: Freedom of Speech and Floor-crossing interface
}

Md. Ziaur Rahman ${ }^{*}$

\section{Introduction}

Democracy is a sine qua non for the administration of a modern State. Modern developed countries are trying to flourish the democratic culture in every sphere of their stately actions. The framers of the Constitution of Bangladesh have made many provisions ensuring the true democracy in many Articles of the Constitution. As part of these, Preamble, Articles 7, 9, 11 and 59 deal with the democratic character of the government. On the other hand, Article 39 deals with the freedom of speech. But Article 70 puts a barrier on the exercise of freedom of vote of the Members of Parliament against his party decision. The provisions of Article 70 of the Constitution of Bangladesh are pushing the democracy in a back seat. This provision does not help the Parliament to uphold the democratic values of the Constitution. By this provision, the freedom of speech as enunciated in Article 39 of the Constitution becomes a useless tool in respect of giving vote inside the Parliament.

This study seeks to find out the relation among democracy, freedom of speech and floor-crossing, to examine the desirability of the provision of floorcrossing, to explore the bad effects of Article 70 in democratic culture of in Bangladesh and to find out the possible way of solving this problem.

\section{Democracy}

Democracy is one of the most comprehensive terms in political science. ${ }^{1}$ There is no uniform definition of democracy. The equality, liberty and fraternity, the sacred slogan of the freedom loving people of France used during the French Revolution is the foundation stone of modern democracy. Equality, liberty and fraternity are inalienable and inherent virtues of modern democratic institutions. ${ }^{2}$ Democracy derived from the Greek word 'demos' or 'people', is defined, basically, as government in which the supreme power is vested in the people. In some forms, democracy can be exercised directly by the people; in large societies, it is by the people through their elected agents. Or in the memorable phrase of President Abraham Lincoln, the $16^{\text {th }}$ President

\footnotetext{
* Assistant Judge, Tangail, Email: ziaur_rahman38@yahoo.com

${ }^{1}$ A.K.M Shamsul Huda, The Constitution of Bangladesh, Istiaq Hasan, Chittagong, 1997,

Vol-1, p. 202

${ }^{2}$ Ibid
} 
of USA, democracy is government "of the people, by the people and for the people." "3otwithstanding such a comprehensive exposition of a democratic government there is no agreed definition of democracy as yet. Democracy may mean a political, social and economic condition in a given society. ${ }^{4}$ It is a process for making collective and authoritative decisions. ${ }^{5}$ In the language of David Bentham 'when we speak of democracy, we have learnt to think of institutional arrangements such as competitive elections, multi-party-ism, the separation of powers, and so forth. ${ }^{6}$ In that sense, democracy is the institutionalization of freedom. ${ }^{7}$

\subsection{Aspects of Democracy}

Foundation of all democracy lies in the Freedom of Speech. ${ }^{8}$ Freedom is an important aspect of democracy. This is manifested in majority rule, and in the centrality of the legislative body through which the people's representatives act. This is a formal aspect of democracy. ${ }^{9}$ The core idea of democracy is that of popular rule or popular control over collective decision making. ${ }^{10}$ Another aspect of democracy is the faith reposed by the people on the higher qualities and leadership abilities of the chosen representatives. It is one of the main purposes of the parliamentary system to inform the voters about the character, charisma, knowledge and other virtues of the elected MPs in order to propel only the gifted individuals forward to the platform of leadership. ${ }^{11}$

\subsection{Democracy in the Constitution of Bangladesh}

In many places of the Constitution of Bangladesh, democracy has taken place as an ornament of Constitution. Democracy is the root through which Bangladesh has managed its place in world map. With the spirit in mind, the

\footnotetext{
${ }^{3}$ http://www.america.gov/st/democracyenglish/2008/May/20080619224145eaifas0.5311657.html. Accessed on 23.05.09

${ }_{5}^{4}$ Supra Note 1

5 Ibid

${ }^{6}$ David Beetham, Democracy and Human Rights: Civil, Political, Economic, Social and cultural Rights, in Dr. Mizanur Rahman (ed), Human Rights and Empowerment, ELCOP, Dhaka, 2001, p.19

${ }^{7}$ Supra Note 3

${ }^{8}$ Supra Note 1, p. 493

${ }^{9}$ Aharon Barak, Protecting a militant democracy, Internet, 10 ${ }^{\text {th }}$ July, 2006, Accessed on 23 April, 2009

${ }^{10}$ Supra Note 6, p. 20

${ }^{11}$ Syed Mujtaba Quader, The Case against 'Article 70', http://nation.ittefaq.com/issues/2007/09/07/news0275.html, Accessed on 02.05.09
} 
makers of the Constitution made democracy available in the following places of the Constitution in bold languages:

\subsubsection{Democracy in the Preamble of the Constitution of Bangladesh}

The word democracy used in the Preamble to our Constitution is one of the fundamental principles of the Constitution. ${ }^{12}$ Democracy has taken place in Para 2 of the preamble of the Constitution of Bangladesh as follows:

Pledging that the high ideals of absolute trust and faith in the Almighty Allah, nationalism, democracy and socialism meaning economic and social justice, which inspired our heroic people to dedicate themselves to, and our brave martyrs to sacrifice their lives in the war for national independence, shall be fundamental principles of the Constitution.

Para 3 of the Preamble states as follows:

Further pledging that it shall be a fundamental aim of the State to realise through the democratic process to socialist society, free from exploitation-a society in which the rule of law, fundamental human rights and freedom, equality and justice, political, economic and social, will be secured for all citizens

Again in Para 4 of the Preamble indirectly democracy has taken place as the embodiment of the will of the people of Bangladesh in the following language:

Affirming that it is our sacred duty to safeguard, protect and defend this Constitution and to maintain its supremacy as the embodiment of the will of the people of Bangladesh so that we may prosper in freedom and may make our full contribution towards international peace and co-operation in keeping with the progressive aspirations of mankind.

\subsubsection{Democracy in Supremacy of the Constitution of Bangladesh}

Article 7(2) clearly and indirectly mentioned about democracy in the following languages:

This Constitution is, as the solemn expression of the will of the people, the supreme law of the Republic, and...

This solemn expression of the people here indicates the majority opinion of the people which is otherwise known as democracy.

\subsubsection{Democracy in Fundamental Principles of State Policy of Bangladesh Constitution}

\footnotetext{
${ }^{12}$ Supra Note 1

${ }^{13}$ The Constitution of the People's Republic of Bangladesh, Article 7
} 
Democracy has been recognized as the fundamental principles of state policy which is as follows:

The principles of absolute trust and faith in the Almighty Allah, nationalism, democracy and socialism meaning economic and social justice, together with the principles derived from them as set out in this Part, shall constitute the fundamental principles of state policy. ${ }^{14}$

\subsubsection{Democracy in Local Government Institutions of Bangladesh}

Provisions have been made to ensure democracy in the root level as:

The State shall encourage local Government institutions composed of representatives of the areas concerned. ${ }^{15}$

\subsubsection{Democracy in the Republic}

Democracy has been extended in administration through elected representatives at all levels as follows:

The Republic shall be a democracy in which fundamental human rights and freedoms and respect for the dignity and worth of the human person shall be guaranteed, and in which effective participation by the people through their elected representatives in administration at all levels shall be ensured. ${ }^{\mathrm{T}}$

\section{Freedom of Speech}

Freedom of speech is a civil liberty. It is one of the basic rights in democracy. The basic rights are the common threads of a democracy. Some democratic nations guarantee it in their Constitutions or bill of rights. For other nations it has evolved through common law. ${ }^{17}$ Freedom of speech and freedom of press are fundamental personal rights and liberties which are the foundation stones of democratic institutions. ${ }^{18}$ Freedom of speech is essential for the development and functioning of democracy. ${ }^{19}$ Without freedom of speech there cannot be any democracy. ${ }^{20}$ The freedom consists of the right to express freely one's conviction and opinion on any matter orally or by writing, printing or any other mode addressed to the eyes and ears of other persons. ${ }^{21}$ Freedom of speech and expression is not confined to any particular field of

\footnotetext{
${ }^{14}$ Ibid, Article 8

${ }^{15}$ Ibid, Article 9

${ }^{16}$ Ibid, Article 11

${ }^{17} \mathrm{http}: / /$ www.google.com.bd/search?hl=bn\&defl=en\&q=define:freedom+of+speech\&ei=PVm RSZiNK4aRgb5yd2VCw\&sa=X\&oi=glossary_definition\&ct=titlem Accessed on 10.02.09.

18 Supra Note 1, p. 494

19 Mahmudul Islam, Constitutional Law of Bangladesh, Bangladesh Institute of Law and International Affairs, Dhaka, 1995, p. 208

${ }^{20}$ Farid Ahmed v. West Pakistan, PLD 1965 Lah 135

${ }^{21}$ Supra Note 19, p. 209
} 
human interest ${ }^{22}$ but guarantees the broadest exercise of the right for religious, political, economic, scientific or informational ends. ${ }^{23}$ In a free democratic society, those who are responsible for public administration must always be open to criticism. Any attempt to stifle or fetter such criticism amounts to political censorship of the most insidious and objectionable kind. ${ }^{24}$

In Dewan Abdul Kader v. Bangladesh ${ }^{25}$ a definition of freedom of speech was given as under:

A right to express one's own opinion absolutely freely by spoken words, writing, printing or in any other manner which may be open to the eyes and ears. It thus includes expression of one's ideas on any matter by any means including even gestures, postures, banners and signs. It thus appears to us that this freedom is wide enough to include expression of one's own original ideas and also expression of one's opinion in the form of comments, explanations, annotations, solutions and answers to questions on the ideas expressed by others.

\subsection{Provision of Freedom of Speech in the Constitution of Bangladesh:}

Freedom of speech has been assured and guaranteed in the Constitution of Bangladesh as follows:

(1) Freedom of thought and conscience is guaranteed.

(2) Subject to any reasonable restrictions imposed by law in the interests of the security of the State, friendly relations with foreign states, public order, decency or morality, or in relation to contempt of court, defamation or incitement to an offence-

(a) The right of every citizen of freedom of speech and expression; and

(b) Freedom of the press, are guaranteed. ${ }^{26}$

\subsection{Restrictions over Freedom of Speech}

If we analyze the Article 39(2) of the Constitution of the People's Republic of Bangladesh, we find some restrictions which are as follows:

a. the interests of the security of the State; $b$. friendly relations with foreign states, c. public order, decency or morality, or d. in relation to contempt of court, e. defamation or incitement to an offence.

These restrictions can be studied on the following headings:

\subsubsection{In the interest of the security of the State}

\footnotetext{
${ }^{22}$ Thomas v. Collins 323 US 516

${ }^{23}$ Douglas v. Jeanette 319 US 157

${ }^{24}$ Hector v. A.G. of Antigua and Barbuda, 19902 All E.R 103, 106

${ }^{25} 46$ DLR 596 p. 599

26 Supra Note 13, Article 39
} 
The security of the State is a matter of concern when there is serious and aggravated form of public disorder as distinguished from ordinary breach of public or public safety which does not involve any danger to the State. ${ }^{27}$ The security of the State is endangered by crimes of violations intended to overthrow the government, ${ }^{28}$ by wagering war or rebellion against the government, or by external aggression or war, but the security of the State is not endangered by minor breaches of public order or tranquility, such as unlawful assembly, riot affray, rash driving and the like. However, incitement to violent crimes like murder which is an offence against public order may endanger the security of the state. ${ }^{29}$ Nowhere in Article 39 of the Constitution of Bangladesh is it said that a Member of Parliament is restricted to vote. So, Article 39 is no barrier to the exercise of the rights of a Member of Parliament to vote according to his choice.

\subsubsection{Public Order}

The expression 'Public order' includes absence of all acts which are a danger to the security of the State and absence of insurrection, riot, turbulence or crimes of violence, but not acts which merely disturb the security of others. ${ }^{30}$

\subsubsection{Friendly relations with foreign States}

Foreign relations are always a touchy matter and the state cannot be embarrassed by irresponsible statements inside the country touching sensitive issues of internal affairs. The object of this restriction on freedom of speech is the prevention of slander and libel against foreign States in the interest of friendly relations with them. ${ }^{31}$ Again Article 25 has been incorporated in the Constitution of Bangladesh which speaks about the friendly relations with foreign States relevant to this regard.

\subsubsection{Decency or morality}

A law may impose reasonable restrictions on speech which lead to undermine public morality. ${ }^{32}$ Whether any speech is likely to undermine decency or

\footnotetext{
${ }^{27}$ Supra Note 19, p. 213

${ }^{28}$ Santokh Singh v. Delhi Administration, AIR 1973 SC 1091)

${ }^{29}$ Bihar v. Sailabala AIR 1952 SC 329

${ }^{30}$ Madhu Limaye v. S.D.M Monghyr, AIR 1971 SC 2486, 2495

${ }^{31}$ Supra Note 19, p. 217

${ }^{32}$ Ranjit v. Maharastra, AIR 1965 SC 881
} 
morality is to be determined to the probable effect it may have on the people to whom it is addressed. ${ }^{33}$

\subsubsection{Contempt of Court:}

In the exercise of his freedom of speech and expression, nobody can be allowed to interfere with the administration of justice ${ }^{34}$ or to lower the prestige or authority of the court even in the garb of criticizing judgment of the court ${ }^{35}$ Freedom of speech and expression is important, but much more important is the effectiveness of the administration of justice without which the rights guaranteed by the Constitution will merely be embellishment. The Appellate Division of the Supreme Court of Bangladesh has observed that 'Freedom of press being recognized in our Constitution, a Court is to suffer criticism made against it, and, only in exceptional cases of bad faith or ill motive, it will resort to law of contempt. ${ }^{36}$

\subsubsection{Incitement to an offence:}

This ground will permit legislation not only to punish or prevent incitement to commit serious offences like murder which lead to breach of public order, but also to commit any offence which according to the General Clauses Act means 'any act or omission made punishable by any law for the time being in force'. ${ }^{37}$ In a free democratic society...those who are responsible for public administration must always be open to criticism. Any attempt to stifle or fetter such criticism amounts to political censorship of the most insidious and objectionable kind. ${ }^{38}$ So, the restrictions as mentioned in Article 39 are not impediment to the freedom of speech in relation to taking or giving any decision inside the Parliament in Bangladesh. Freedom of speech and expression is not confined to any particular field of human interest ${ }^{39}$ and but guarantees the broadest exercise of the right of religious, political, economic, scientific or information. ${ }^{40}$ So, freedom of speech is only curtailed when it affects the security of Bangladesh, friendly relations with foreign States, public orders, decency and morality, etc. Nothing said about the restrictions

\footnotetext{
${ }^{33} R$ v. Secker \& Warburg 1954 Wlr 1138

${ }^{34}$ Namboodripad v. Nambair, AIR 1970 SC 2015

${ }^{35}$ Daphtary v. Gupta, AIR SC1132

${ }^{36}$ Saleemullah v. State 44 DLR 309 p. 313

${ }^{37}$ Supra Note 19, p. 220

${ }^{38}$ Supra Note 24

39 Supra Note 22

${ }^{40}$ Supra Note 23
} 
that are put on Article 70 in exercising the rights of personal liberty by the Member of Parliament in case of giving his verdict on a bill in the Parliament.

\section{Whether a member of parliament is restricted to express his freedom of speech in parliament except Article 70?}

A Member of Parliament has unqualified absolute immunity in respect of any freedom of speech made by him in Parliament and in any committee thereof ${ }^{41}$ and the court has no jurisdiction to proceed against him for what he said in Parliament or in any committee of Parliament, whether the statement is true or false and whether the statement is made in good faith or maliciously. ${ }^{42}$ No legal action would lie against such Member in view of the freedom of his speech guaranteed to the Member of Legislature inside the four walls of the house. ${ }^{43}$ A Member of Parliament is protected for what he said in parliament, but not for anything said outside parliament. It is to be noted here that the Members of Parliament can say anything they like inside the house but in case of giving vote in respect of taking a decision he is prohibited by Article 70 to his party decision. It may also be mentioned here that a Member of Parliament shall not be liable to proceedings in any court in respect of anything said, or any vote given, by him in Parliament or in any committee thereof. ${ }^{44}$ Here comes the question whether there is any restriction on the freedom of speech of a Member of Parliament? Or whether he is free to say anything he likes outside the Parliament? The answer to the question is no. Because he is under the same restrictions as mentioned in Article 39 just like an ordinary citizen. The glaring example of this has been established in Mianul Hossain and others V. Sheikh Hasina ${ }^{45}$ wherein the fact of the case was that she (Sheikh Hasina) gave an interview with the correspondent of the British Broadcasting Corporation where she made some objectionable and contemptuous statement undermining the image, honour, dignity and prestige of the Courts of Bangladesh as a whole and it has been held by the honourable High Court Division that the application for drawing up of proceeding of contempt of court against Sheikh Hasina, the Prime Minister of Bangladesh are disposed of with a note of desire that the honourable Prime Minister shall be more careful and respectful in making any statement or comment with regard to the Judiciary or the judges or the Courts of Bangladesh in future. But in case of

\footnotetext{
${ }^{41}$ Ataur Rahman v. Md. Nasim, 52 DLR 16

${ }^{42}$ Powell v. McCormack, 395US 486

${ }^{43}$ Cyril Sikdar v. Nazmul Huda, 46 DLR 555 p.560

${ }^{44}$ Supra Note 13, Article 78(3)

${ }^{45}$ Mianul Hossain and others v. Sheikh Hasina 53 DLR (2001) 138
} 
giving vote and in respect of taking a decision he is prohibited by the article 70. So, the Members of Parliament are not absolutely free to say anything they like outside the Parliament but the restrictions in Article 70 should not be taken as desirable as it is opposed to the idea of personal liberty of the Member of Parliament and which is also against the concept of majority rule and thereby curb the democratic aspect of the Constitution of Bangladesh.

\section{What is floor-crossing?}

The term floor-crossing is a common issue in every democratic country. The term 'political defection' is otherwise called 'floor-crossing' or 'side swapping' which means resignation from one's own party or desertion of a political party in order to join another one. ${ }^{46}$ The term floor-crossing in the constitutional and political terminology generally means to cross one members own party floor to another floor at the time of voting in the House. ${ }^{47}$ That means floor-crossing takes place when one Member of Parliament ultimately leaves his or her political party in order to join another party or becomes an independent candidate. The term was first used to describe the process when Members of the British House of Commons crossed the floor to join the group of people (members of another political party) that was seated on the opposite site of the floor. ${ }^{48}$

\subsection{Object of floor-crossing or side swapping}

There may be two types of objects of floor-crossing. One of them may be the denial or defiance of the party decision and the other may be the personal interest of the particular Member of Parliament.

As regards the first, the object is to flourish the democratic character of the particular Member of Parliament. Here he is opposing because the party decision is not democratic. Better example of this is Mr. Major (Rtd.) Md. Aktaruzzaman, BNP lawmaker who was elected from Kishorganj-2 constituency in June 1996. He alone joined the Parliament Sessions violating

\footnotetext{
${ }^{46}$ Md. Abdul Halim, Constitution, Constitutionalism and Politics: Bangladesh Perspective, $2^{\text {nd }}$ Edition, Published by Yousuf Ali Khan, Dhaka, 2003 p. 175

${ }^{47}$ Ibid

${ }^{48} \mathrm{http}$ ://en.wikipedia.org/wiki/crossing_the_floor\#Voting_against_party_lines Accessed on 05.02.09
} 
party decision ${ }^{49}$ but the BNP did not join in the $19^{\text {th }}$ Session of Parliament on 10.09.2000.

As regards the second, the object of floor-crossing is the personal interest. In most cases the Members of Parliament crossed the floor for personal interest. Better example is that "he (Kazi Sirajul Islam who was elected Member of Parliament from Faridpur-1 constituency in Awami League ticket in the General Election of 2001 crossed the floor into the ruling party Bangladesh Nationalist Party (BNP) on June 4, 2005) joined the BNP to settle a business deal of Tk. 1.4 crore or so. It is thus alleged that he left the AL and joined the ruling BNP in order to settle the business deal as well as to save himself from the due process of law for his alleged involvement in immoral activities. ${ }^{50}$

\subsection{Rationale behind prohibiting the floor-crossing}

Floor-crossing has been provided in Article 70 just to sustain the stability and smooth functioning of the government and for effective government. Honourable Speaker to the eighth Parliament Barrister Jamiruddin Sircar defended Article 70 of the Constitution which prohibits floor crossing by Parliament Members, saying it would help strengthen and stabilize parliamentary democracy in the country." ${ }^{, 51}$ Some of the Constitutional experts argue that Article 70 of our Constitution "was framed after much thought to ensure stability and strengthen parliamentary democracy". ${ }^{2}$ That the compulsion for the inclusion of Article 70 in the original Constitution of 1972 and the amendments thereof up to 12 amendment, 1991 can be traced back to the bitter experience in the past when floor crossing and horse trading, to make and break governments become a matter of concern for all. ${ }^{53}$ In order to achieve stability and continuity of government, at least for the term it is elected, Article 70 of the Constitution ensures a healthy, stable and viable Parliamentary democracy in the country by way of maintaining party discipline. $^{54}$

\subsection{How far this rationale is acceptable in the context of Bangladesh?}

\footnotetext{
${ }^{49}$ Khondker Delwar Hossain, M. P. v. Major (Rtd) Md. Aktaruzzaman, M.P, Case no. 1 of 2000 before the Election Commission

${ }^{50} \mathrm{http}: / /$ www.thedailystar.net/2005/06/13/d50613020430.htm Accessed on 26.04.09

${ }^{51}$ The Daily Independent, November 29, 2004

${ }^{52} \mathrm{http}: / /$ www.thedailystar.net/2005/06/13/d50613020430.htm. Accessed on 11.02.09

5351 DLR 1, para-11

${ }^{54}$ Supra Note 51
} 
Stability may be maintained otherwise. Thinking like that the government will hold its office for five years as fixed in Article72 (3) unless and until it is dissolved by the President. When a vote of censure or no-confidence is brought against particular government, the concerned Member of Parliament shall invariably vote for the party on whose ticket he was elected. By this practice in Parliament, the stability of the government may be maintained. But no way the Member of Parliament should be freed to cross the floor to join another or ruling party to gratify his immoral lust. It is further argued that some parliamentary democracies having no such thing as Article 70 of our Constitution have not suffered from political instability. ${ }^{55}$ In a conference, supported by various German institutions, was organized by "Bangladesh in Lower Saxony" (AK BiN), the speakers of the conference urged the stakeholders of Bangladeshi politics to review the Constitution of Bangladesh to consolidate and sustain democracy, and in this respect, suggested amending Article 70, which deprives MPs of freedom to exercise their own judgment. ${ }^{56}$

\subsection{Provision of Floor-crossing in the Constitution of Bangladesh}

As a form of government democracy means a government in which the man of adult population has a direct or indirect share. Our Constitution aims at a representative democracy based on universal adult franchise without any restriction in all cases except under Article 70. Article 70 reads as follows:

A person elected as a Member of Parliament at an election at which he was nominated as a candidate by a political party shall vacate his seat if he resigns from that party or votes in Parliament against the party.

The term 'resign' may have an extended meaning. It has been held in Secretary, Parliamentary Affairs v. Khondker Delowar Hossain ${ }^{57}$ that joining the Ministry formed by one party after being elected on the nomination of another party may sometimes constitutes resignation from the latter party within the meaning of Article 70. Resignation by conduct or otherwise against party discipline and dictates is also envisaged under these Articles. ${ }^{58}$

Resignation from the party on whose ticket he was elected shall not be the ground of the vacation of his seat in Parliament rather he should be continued to be treated as an independent candidate for rest period of the Parliament.

\footnotetext{
${ }^{55} \mathrm{Ibid}$

${ }^{56}$ http://www.thedailysatr.net/magazine/2008/11/03/event.htm

57 1999 BLD 276

58 DLR 1 p 10
} 
Again, he should not be permitted to join another political during the existence of the concerned Parliament because in both cases, he was elected to Parliament as the nominee of his earlier party and the people voted him to carry into effect the manifesto of that political party. So, if he resigns from his party and if he is willing to join another political party in the Parliament he should be subjected to re-election. Now it is the people who will decide his fate in Parliament.

Again, the term 'vote' has been given two connotations by the Constitution (Fourth Amendment) Act, 1975 as:

If a member of Parliament-(a) being present in Parliament abstains from voting, or (b) absents himself from any sitting of Parliament, ignoring the direction of the party which nominated him at the election as a candidate not to do so, he shall be deemed to have voted against that party. ${ }^{59}$

It does mean that Members of Parliament is bound to follow the direction of his political party. His ignorance of the party direction shall be treated as he voted against his party and as a result of this, his seat in Parliament will be vacated. Is it democracy? This is opposed to the idea of democracy as the opinion of the people is not reflected through the elected representatives.

According to paragraph 2 of the Tenth Schedule of the Constitution of India, a Member of either House (Council of States or House of People) of Union Parliament or of the Legislative Assembly of a State belonging any political party shall be disqualified from being a Member of the House (a) if he has voluntarily given up his membership of such political party; or (b) if he votes or abstain from voting in such House contrary to any direction issued by the political party to which he belongs without obtaining the prior permission of such political party and such voting or abstention has not been condoned by such political party within fifteen days from the date of such voting or abstention.

The provisions of the Constitution of India in this respect that according Article 63A of the Constitution of Pakistan, a Member of a House (the National Assembly or the Senate) or of the Provincial Assembly shall lose his seat if he defects from a political party which nominated him or votes contrary to any direction issued by the parliamentary party to which he belongs, or

${ }^{59}$ Supra Note 13, Explanation to Article 70 
abstains from voting in the House against party policy in relation to a bill. $\mathrm{He}$ however gets an opportunity to appeal and the party chief's decision is final.

\subsection{Whether democracy has been pushed to back seat by Article 70?}

If we analyze article 70 we will find that a person elected as Member of Parliament shall vacate his seat if he-

a. resigns from that party which nominated him at the election, or

b. votes in Parliament against the party.

It is taken that a Member of Parliament has democratic right to resign from his political party. But question comes when a member of parliament resigns from his political party to join another political party or the ruling party. Can he resign and at the same time join another party or the ruling party? Should the Constitution permit him to do so? Definitely, he should not be permitted to do so. Because, it would amount to breach of trust with the people who voted him to Parliament as well as the betrayal of his own oath that "I will not allow my personal interest to influence the discharge of my duty as a Member of Parliament. $^{60}$

A member of parliament can not vote against the party or against the party decision, which nominated him at the election due to the operation of Article 70. Thereby the personal liberty of a Member of Parliament has been curbed and the democracy inside the parliament in case of decision making has been push to death. Because, simple majority or two thirds majority is necessary in case of passing a bill which is placed before the Parliament and that the Members of Parliament are bound to give vote in favour of his political party which nominated him at the election under Article 70. Otherwise his seat will be vacated.

\subsection{Floor-crossing in Bangladesh Perspective: Case Studies}

Floor-crossing is not a new matter in Bangladesh. There are many instances of it in Bangladesh. Some of them are picked here for discussion.

In the first instance, it can be mentioned about the floor-crossing that happened in the fifth Parliament. it is stated that "three Members of the fifth Parliament namely, Mr. Ebadur Rahman Chowdhury, Major General Mahmudul Hasan and Mr. Paritosh Chakroborty, all belong to Jatiyo Party

${ }^{60}$ Supra Note 13, Article 148. 
joined the Bangladesh Nationalist Party in 1995. The matter was referred by the then Speaker to the Election Commission. After hearing, the Election Commission declared the seats had fallen vacant and communicated the decision vide letter dated 30.08.95 to the Speaker and upon which gazette notification to that effect was published."

In the second instance, it can be traced back to seventh Parliament in which "two persons (namely Md. Habibur Rahman Shawpon and Dr. Alauddin were elected in the general election held on June 12, 1996 from the National Constituency No. 67, Sirajganj-7 and National Constituency No. 56, Rajshahi5 respectively) were elected on the nomination of Bangladesh Nationalist Party (BNP) and that they were appointed as ministers by the ruling party. They did not resign from Bangladesh National Party, but Bangladesh National Party wrote letters requesting the Speaker to publish notification under rule 178 of the Rules of Procedure stating that they vacated their seats as Members of Parliament as their conduct amounts to resignation from Bangladesh National Party. The Speaker refused to publish the notification or to refer to the Election Commission. The Speaker took the stand that there was no allegation of resignation or voting against Bangladesh National Party and as such there was no dispute to be referred to the Election Commission. The Appellate Division, affirming the judgment of the High Court Division, held that the facts and circumstances of the case disclosed a dispute regarding the alleged resignation of the two members and the Election Commission is the authority designated by the Constitution to determine the question as to what is meant by resignation and whether the two members resigned, and accordingly directed the Speaker to refer the matter to the Election Commission. ${ }^{62}$ The Speaker then referred the matter to the Election Commission which held that joining the Ministry of the ruling party constituted resignation from Bangladesh National Party attracting the mischief of Article $70 .{ }^{63}$

In the third instance, in the seventh Parliament in which, on the other hand, another Member of Parliament (Anwar Hossain Monju) elected on the nomination of Jatiyo Party did not fall within the mischief of Article 70 by joining the Ministry of the ruling party as the said Member joined the

\footnotetext{
${ }^{61}$ Khondker Delwar Hossain and another v. Speaker, Bangladesh Jatiyo Sangshad (Parliament and another) 51 DLR 1, Para 10

${ }^{62}$ Supra Note 56 p.351-352.

${ }^{63}$ Ibid
} 
consensus government of the ruling party with the consent of the Jatiyo Party and its leader. ${ }^{64}$

In the fourth instance, in $8^{\text {th }}$ Parliament, "Kazi Sirajul Islam, who was elected Member of Parliament (MP) from Faridpur-1 constituency on Awami League ticket in general election of 2001, crossed the floor into the ruling-party Bangladesh Nationalist Party (BNP) on June 4, 2005. Upon a petition filed by the Awami League, the Speaker of Parliament declared on June 9, 2005 the parliamentary seat of Faridpur-1 vacant following the defection of Kazi Sirajul Islam." $" 65$

\section{Article 70 is contradictory to the fundamental rights of MPs:}

Political defection is a democratic right connected with personal liberty and freedom of thought and speech. Right to vote against party decision, or to be absent in the house in protest of party's undemocratic decision, or abstain from voting, is connected with the personal liberty of a Member. A Member of the Legislature who is elected directly by the people is always expected to act in a democratic sprit. People's mandate is reposed on him not to act on undemocratic party line but to raise voice against whimsical or undemocratic decisions. ${ }^{66}$ But as the provision goes in Article 70 , no Member of the ruling party can exercise his right to dissent even when the government passes an undemocratic law. ${ }^{67}$ As a result of this, the dark laws that grossly violate human rights and are used to harass innocent citizens. ${ }^{68}$

Some constitutional experts and members of civil society argue that Article 70 of our Constitution "contradicts the fundamental rights as enumerated in part iii of the Constitution, thereby curbing the rights of the MPs also, as far as freedom of thought and expression is concerned". 99

\subsection{Article 70 undermines the sprit of responsible government and leads to elective dictatorship in Bangladesh}

In a parliamentary democratic country the government is directly responsible to the legislature but no provision for individual responsibility has been nor does it exist in the political culture. Provisions are made in the Constitution

\footnotetext{
${ }^{64}$ Ibid

${ }^{65} \mathrm{http}: / /$ www.thedailystar.net/2005/06/13/d50613020430.htm. Accessed on 26.04.09

${ }^{66}$ Supra Note 46 p. 180

${ }^{67}$ Ibid p. 46-47

${ }^{68} \mathrm{http}: / /$ www.drishtipat.org/HRLaw/index.htm Accessed on 26.04.09

${ }^{69} \mathrm{http}: / / \mathrm{www}$. thedailystar.net/2005/06/13/d50613020430.htm Accessed on 26.04.09
} 
for collective responsibility to that effect that the cabinet shall be collectively responsible to Parliament'. ${ }^{70}$ But ironically enough, this provision for collective responsibility has become a soundless vessel because of Article 70 as the cabinet is always sure that it is not to be defeated by motion of noconfidence or confidence, for no member of the majority party has the right to vote against the party. ${ }^{71}$

\subsection{Article 70 is a great hindrance to ensuring rule of law in the country}

Rule of law as distinguished from rule of man and party, means rule of that law which is passed in democratically elected Parliament after adequate discussion and deliberation. When there is the scope of adequate deliberation and discussion over a bill, it creates environment to remove undemocratic provision from it. But because of Article 70 no dissenting opinion can be made by the members of the ruling party and as a result every bill, however undemocratic it may be, gets quickly passed or approved. ${ }^{72}$

\subsection{Relationship between democracy, freedom of speech and floor- crossing}

There is close relation among these three. Without freedom of speech there can be no democracy. Freedom is an important aspect of democracy. Foundation of all democracy lies in the "Freedom of Speech."73 But that aspect has been treaded by providing the provision for floor-crossing in Article 70 in the Constitution of Bangladesh. In Romesh Thappar v. State of Madras it has been held by the Indian Supreme Court that "Freedom of speech and expression includes freedom of propagation of ideas, and that freedom is ensured by the freedom of circulation." 74 This freedom of circulation has been totally violated by providing Article 70 in the Bangladesh Constitution. Provisions relating to democracy have been inserted in preamble and in Articles 7, 8, 11 to the Constitution but all aspects of those provisions have been curtailed by providing Article 70 in so far as it is opposed to the majority rule. So for the smooth functioning of democracy through the power of freedom of speech in case of giving decision by the Member of Parliament, Article 70 should be amended.

\footnotetext{
${ }^{70}$ Supra Note 13, Article 55

${ }^{71}$ Supra Note 46 p. 181.

${ }^{72}$ Ibid, p. 182

${ }^{73}$ Supra Note 8

${ }^{74}$ AIR 1950 SC 124
} 
The restrictions that are imposed by law under Article 39 in case of exercise of freedom of speech is subjected to the security of the State, friendly relations with foreign States, public order, decency or morality or in relation to contempt of court, defamation or incitement to an offence. Thus none of these restrictions relates to the decision making process by the Members of Parliament. So there is no bar on the Members of Parliament in Article 39 to express his freedom but Article 70 is a bar to that end.

\section{Recommendations:}

After the above discussion on democracy, freedom of speech and floorcrossing in the light of our Constitution, the following measures are recommended to be taken to ensure parliamentary democracy through the medium of freedom of speech of the members of parliament:

7.1. A Member of Parliament has every right to resign from his political party. This is his constitutional right as guaranteed in Articles 31 and 32. Mere resignation from his political party should not be the ground of vacation of his seat in Parliament. If it would happen then Article 67(2) will be meaningless. It provides for the resignation from of the Membership of the Parliament not from the Party. He should be treated as an independent candidate in case of resignation from his party.

(a) But he should not be allowed to resign from his party to join another party in Parliament or cross the floor to gratify his undemocratic lust because the people elected him as the nominee of that political party. So, he is under a moral obligation not to join with another political party for his personal interest. Because he undertakes on his shoulder the responsibility to carry into effect the manifesto of his own political party. Again, he can not violate the oath he has taken, having been elected a Member of Parliament. ${ }^{75}$ That is why if any Member of Parliament resigns from his political party to join another political party for personal gain during the existence of the Parliament, he should be subjected to re-election. So, Article 70 should be amended to the effect that if any Member of Parliament resigns from his political party to join another political party for personal interest during the existence of the Parliament, his seat in Parliament will be vacated and he should be subjected to re- election. Now the people will decide his fate in

\footnotetext{
${ }^{75}$ Oath of Office provided in the Third Schedule of the Constitution of the People's Republic of Bangladesh said that "And I will not allow my personal interest to influence the discharge of my duties as a Member of Parliament."
} 
Parliament. As a result of these amendments, democracy as well as party discipline will be maintained in Parliament. But the meaning of personal interest is very uncertain that is why the Parliament should, by making law, provide the meaning of it.

(b) In second case, if a Member of Parliament resigns from his political party in defiance of the decisions of his party, his seat should not be vacated and he should be treated as an independent candidate as if he were elected as a Member of an independent candidate for the rest period of the Parliament. Just the opposite of Article 70 (3) that if a person, after being elected a member of Parliament as an independent candidate, joins any political party, he shall, for the purpose of this Article, be deemed to have been elected as a nominee of that Party. So, amendments should be made to Article 70 in that behalf.

(c) In third case, if he does not resigns from his political party but votes in Parliament against that party except the following three, he should continue to be regarded as a Member of Parliament as well as a candidate of his political party. So, necessary amendments should be made to Article 70 inserting the provisions relating to the rights of a Member of Parliament for voting in Parliament freely except in the following three cases.

7.2. The rationale behind the provision for floor-crossing is that to sustain the stability of government and strengthen the smooth functioning of the government and for effective government which can be maintained by making laws in this regard. So, explanation to Article 70 should be amended inserting the provisions that Member of Parliament should be freed to vote in accordance with their conscience except on three fundamental and vital issues,

a. when a vote of censure or no-confidence is brought against a particular government, the concerned MP shall invariably vote for the party on whose ticket he was elected;

b. he shall not vote against the Finance Bill or against the smooth passage of the Annual Budget so that the financial activities of the government should not be harassed;

c. on sensitive defence matters which may be debated in camera, if needed. Because this is not the concern only of a political party but the concern of all people living in Bangladesh.

In other cases Member of Parliament should be allowed to speak and vote freely maintaining the decorum of the House. As a result of these amendments, democracy as well as stability of government can be maintained. 


\section{Concluding Remarks:}

The Constitution of Bangladesh in its preamble states that democracy will be the ultimate goal of the government and government will ensure democracy. But to ensure democracy, freedom is an important aspect. This aspect of democracy is manifested in majority rule, and in the centrality of the legislative body through which the people's representatives act. But this representation is not possible under the present Constitution of Bangladesh because of Article 70. Article 39 rightly mentions no restriction in case of exercising the right to vote inside the Parliament. Again, Article 78(3) prescribes immunity to the Members of Parliament in exercising his right to vote that he will not be liable to proceedings in any court in respect of the publication of vote by the authority of Parliament. But Article 70 is contrary to the spirit of the democratic character of the Constitution. Now it is high time to think over it. In $8^{\text {th }}$ and $9^{\text {th }}$ Parliamentary election it is seen that the ruling party got more than two-third majority. So, this is high time to amend Article 70 as recommended above. Otherwise, the proper functioning of the democratic government which is ultimate aim of the Constitution of the People's Republic of Bangladesh will be an unfulfilled dream. 